\title{
Recovery of the Education System in Myanmar
}

Khaing Tharaphy *

Ministry of Education, Myanmar

\section{ARTICLE INFORMATION}

\section{Article history:}

Data submission : August 20, 2019

$1^{\text {st }}$ revision: August 25, 2019

Accepted: September 12, 2019

Available online: December 12, 2019

Keywords: Myanmar; education; development; Southeast Asia; reform.

\begin{abstract}
Myanmar's education system is very weak with the least national budget allocation. The condition of physical infrastructure and human resource capacity of the system is also very poor without standard facilities and professional teachers. Whether in schools, colleges or universities, there is very few opportunities and little incentive for professional development. A process of recovery is getting underway, but it will take years before significant improvements for evidence. Major cultural change is required in the style of leadership and management at all levels of government, and there is a desperate need for more financial resources. This paper documents the current state of the education system in Myanmar and advances certain priority areas for immediate attention.
\end{abstract}

2019 FIA UB. All rights reserved.

\section{Introduction}

Myanmar's democratic transformation from over (50) years of military dictatorship to civil society is still stocked with political and social challenges. The country remains the poorest among its neighboring nations with its weak educational system, lacks with physical infrastructures, with old-fashioned teaching methods and untrained teachers with little incentive professional development. Therefore as starting point, its educational approach updates would take longer process of recovery.

This paper try to present the findings based on interviews with students, teachers and educational managers within the period from 2011 to 2013, together with the available literature, and recent publications by one of its authors, Martin Richard, (2011, 2013), and from some official the reports in English.

\section{Discussion}

\subsection{The Setting}

Myanmar is the "least developed nation" despite of its (60) million population with a large landmass and

\footnotetext{
* Corresponding author email; khaiangtharapy@gmail.com
}

with the GDP level per capita, between USD 800 and 1,000 (World Bank, 2013). Its only agriculture which significantly generates (43\%) of GDP, providing livelihood for over $(70 \%)$ of its population, (World Bank, 2013). However, its Human Development Index remains relatively low and poverty also affects over (25\%) of its population (UNDP, 2013: World Bank, 2013).

Ethnic diversity composed of (135) ethnic nationalities becomes distinctive characteristic of Myanmar. The Burmans, (68\%), live in the lowland which economically well-developed regions of the country. In fact the new democratic parliamentary has been limited in which the military retains control over one-quarter of the seats. Ethnic rivalries have not yet disappeared, and military action to control civil unrest continues in several parts of the country.

In February 2012, the Ministry of Education, with the funds from an international consortium of development partners, initiated a Comprehensive Education Sector Review (CESR), to promote a "learning society capable of facing the challenges of the Knowledge Age". This review gives us hope that the 
State is becoming more committed to ensuring that every child in Myanmar should have the opportunity to complete a full cycle of basic education of good quality.

\subsection{Basic education}

Basic education in Myanmar currently consists of five years of primary education, four years of junior secondary education, and two years of senior secondary education. Primary school education is compulsory, but the net enrolment rate in primary school in 2010-11 was estimated to be only $84.6 \%$ (MOE, 2012b), indicating that not all primary school students remain until successfully completing primary school at the end of grade (5). By grade (6), only about $(50 \%)$ of students remain enrolled and this loss continues until grade (10) only $(23 \%)$ of students enrolled. Some of the loss of students during the secondary might be due to unaffordability and inaccessible, with selective nature of the examination system. Young people from rural areas, and especially from poorer households, are the least likely to remain in school through to the final year.

\subsection{Vocational and Higher Educational}

The Ministry of Science and Technology try to manage a national network of technical universities, technological colleges and technical institutes, offering degree and diploma qualifications. So that upon the completion, the students could find employment as they acquire knowledge and skills relevant to their future workplaces.

The Technical and Vocational Education and Training (TVET) sector has many deficiencies, with limited relevance of curricula, materials, methodologies, and program designs; the lack of an alignment across TVET, higher education, and secondary education; quality control and accreditation, particularly in the context of a proliferation of institutions and programs of varying quality; inadequacies in the qualifications of teaching staff and in the quality of professional support systems; and weaknesses in links to labor market demand, especially in emerging sectors and skill areas (ADB, 2012,: p.26).

\subsection{Challenges}

Myanmar's education system faces enormous challenges in relation to finance, governance and management, pedagogy, equity, and quality. They also exist in different forms across the school, TVET and higher education sectors.

\subsection{Finance}

Since under the dictatorial rule, the education system has been grossly underfunded. Only (4.4\%) allocation of the national government's budget has been availed to education. Not surprisingly, total expenditure on education as a proportion of Myanmar's GDP is also very low.

Even the salaries for teachers are relatively unattractive, and the graduates are less inclined to pursue a career in teaching. Due to insufficient funds, schools, colleges and universities are typically in a very poor physical condition, with inadequate or even nonexistent library and laboratory resources.

\subsection{Governance and Management}

Issues of governance about higher education sector, has no self-governing capacity. The University Education Law of 1973 effectively deprived universities and institutions from institutional and financial autonomy. Within universities and institutes, any decision to be made tend to be purely procedural in nature, which is one of top-down decision making. The curriculum in schools is also centrally determined, with negligible regard to local needs and circumstances. Myanmar's education system has no vision that is realistic and unifying. The education system might well be better off focusing on a vision with long-term strategic importance of quality, efficiency, unity, equity and internationalization.

\subsection{Pedagogy}

Fundamental challenges exists in relation to pedagogy. Myanmar's rigid school examination system still dominates the education system. With failure rates high, success in examinations became an important target of education." (MOE, 1992) Teachers feel compelled to teach what will be tested, and students are inclined to learn only whatever might be on the exam. Teaching quality and teaching methods at all levels of the education system in Myanmar need so much improvement.

The reality is that most Myanmar students cannot think critically, raise questions or solve problems. The success of new approaches will only be affective based on the availability of more library resources and by students and teachers having more freedom to access to the Internet.

\subsection{Equity}

With regard to Equity issues, most of young people from rural areas, and poorer households, are the least likely to remain in school to the final year. And traditional gender inequity, with boys succeeding at the expense of girls, is not immediately evident in Myanmar. Girls are in fact, over-represented among higher education students. The teaching profession is 
predominantly (86\%) female (UNESCO, 2011a) because girls want to become teachers and remain in school to continue higher education. In monastic schools, Buddhist monks provide supplementary education for needy children and orphans - filling a significant gap in the education system.

\subsection{Quality}

Myanmar is a member of the Asia-Pacific Quality Network, the ASEAN Quality Assurance Network, the University Mobility in Asia and the Pacific organisation, the ASEAN University Network, the Association of Southeast Asian Institutions of Higher Learning, and the Association of Pacific Rim Universities, but it is at a very elementary stage in terms of developing a quality assurance system for its higher education sector. Legislation regarding the quality and academic standards of the higher education sector was never approved. The lack of institutional autonomy and the slowness of centralized decision-making are significant impediments to progress.

\subsection{Priorities for Improvement}

Many aspects of Myanmar's education system require improvement. The education system needs more public funds since the physical infrastructure of schools, colleges and universities is in bad shape, with buildings to be repaired, libraries needing to be restocked, and laboratories needing to be reequipped. Primary school teachers require more support. Providing more public funds to achieve an improvement will not be effective if the skills, attitudes and levels of commitment of primary school teachers are not addressed. There is a most pressing need to improve the training, professional development and remuneration of the teachers.

\section{Conclusion}

This paper has sought to document the current state of the education system in Myanmar, and identify selected priority areas for attention. A great deal of destruction has been wrought on the system by over (50) years of military rule. The younger generation in Myanmar need to develop and share a common vision for the system, which is inspiring and well integrated with global needs. They will need the freedom from the present culture of centralized control and top-down bureaucracy. Therefore, education services in Myanmar is indeed crucial concern, not only for the younger generations but also for the future of the nation, that everybody should take certain initiatives in order to promote and implement such qualitative educational services in Myanmar. International aid organizations have a great deal of responsibility for helping to identify and develop these future leaders. In fact, the recovery process can be slow and difficult but we have hope for brighter future.

\section{References}

Asian Development Bank (ADB) (2012). Myanmar in transition: opportunities and challenges. Manila: ADB.

Buncombe, A. (2013). Why Burma is going back to school. The Independent. Myanmar: USA.

Hayden, M., \& Martin, R. (2011). The education system in Cambodia: making progress under difficult circumstances. In C. Brock \& L.P. Pe Symaco (Eds.). Education in South-East Asia. Oxford: Symposium Books.

Hayden, M., \& Le T.N.L. (2013). The education system in Vietnam: a need to improve quality In L.P.

Pe Symaco (Ed). Education in South-east Asia. London: Bloomsbury.

Htet, T.L.Z. (2013). Burma parliament approves controversial defense budget. The Irrawaddy. Available http://www.irrawaddy.org/archives/28162.

[Accessed 1 June 2013].

Martin, R. (2011). Education in Myanmar: opportunity for limited engagement. In Brock \& L.P. Symaco (Eds.). Education in South-East Asia. Oxford: Symposium Books.

Martin, R. (2013). Myanmar: Governance, civil society and the development of education. In L.P. Symaco (Ed.). Education in South-East Asia. London: Bloomsbury.

Ministry of Education (MOE) (1992). Education sector study: final report. Report for the Myanmar Education Research Bureau. Yangon: Ministry of Education.

Ministry of Education (MOE) (2012a). Education development in Myanmar. Yangon: Ministry of Education.

Ministry of Education (MOE) (2012b). Access to and quality of education: education-for-all in Myanmar. Yangon: Ministry of Education.

Organisation for Economic and Cultural Development (OECD) (2011). Public spending on education. Moec: Myamnar.

Naing, K.S. (1992). Student evaluation. Report for the Myanmar Education Research Bureau. Yangon: Ministry of Education.

Oxford Burma Alliance (2013). Ethnic nationalities of Burma. Available at http://www. oxfordburmaalliance.org/ethnic-groups.html. [Accessed 1 June 2013].

Reuters (2013). Foreign investment jumps fivefold in Burma. The Irrawaddy. Available at http:// www.irrawaddy.org/archives/34427. [Accessed 1 June 2013]. 
Sampson, P. (2013). Burma can quadruple economy by 2030, Report says. The Irrawaddy. Available at http://www.irrawaddy.org/archives/36052.

[Accessed 1 June 2013].

United Nations Children's Fund (UNICEF) (2011). Multiple indicator cluster survey 2009-10. Available http://reliefweb.int/sites/reliefweb.int/files/resourc es/MICS_Myanmar_Report_2009-10. pdf. [Accessed 1 June 2013].

United Nations Development Programme (UNDP) (2011). Integrated household living conditions survey in Myanmar (2009-2010): poverty profile. Available at http://www.mm.undp.org/ IHLCA/. [Accessed 1 June 2013].

United Nations Development Programme (UNDP) (2013). International human development indicators. Available at http://hdrstats.undp.org/en/countries/profiles/MM R.html. [Accessed 1 June 2013].

United Nations Educational, Scientific and Cultural Organization (UNESCO). (2011a). World data on education: Myanmar. Available at http://www.ibe.unesco.org/fileadmin/user_upload/ Publications/WDE/2010/pdfversions/Myanmar.pdf. [Accessed 1 June 2013].

United Nations Educational, Scientific and Cultural Organization (UNESCO). (2011b). International standard classification of education. Available at http://www.uis.unesco.org/Education/

Documents/UNESCO_GC_36C-

19_ISCED_EN.pdf. [Accessed 1 June 2013].

World Bank (2013). Myanmar overview. Available at http://www.worldbank.org/en/country/

Myanmar/overview. [Accessed 1 June 2013]. 